\title{
Green Needlegrass Seedling Morphology in Relation to Planting Depth
}

\author{
TIMOTHY E. FULBRIGHT, A.M. WILSON, AND EDWARD F. REDENTE
}

\section{Abstract}

Green needlegrass (Stipa viridula Trin.) is commonly used in range seedings and revegetation of disturbed lands in the northern Great Plains. This study was conducted to determine the influence of planting depth, seed source, and temperature on morphology and emergence of green needlegrass seedlings. Seeds from 2 sources were planted at depths of $1.5,3.0,4.5,6.0$, and $7.5 \mathrm{~cm}$ in pots filled with sandy loam soil. Pots were placed in growth chambers adjusted for either a $20 / 15^{\circ} \mathrm{C}$ (15 h light/9 h dark) temperature regime or a $25 / 20^{\circ} \mathrm{C}$ regime. Coleoptile length increased with planting depth, while seminal primary root length, adventitious root length, and number of adventitious roots decreased with planting depth. 'SD-93' seedlings had shorter subcoleoptile internodes, longer coleoptiles, and better root development than 'Lodorm' seedlings. Seedlings grown under the warmer temperature regime had better root development than seedlings grown under the cooler regime, but reach of the coleoptile above planting depth was not as great. Results indicated that green needlegrass generally should not be planted at depths greater than $3.0 \mathrm{~cm}$ because of lower percent emergence, rate of emergence, and poor root development when seedlings emerged from greater depths.

Green needlegrass (Stipa viridula Trin.) is a native, cool-season perennial bunch grass that ranges from Alberta and Saskatchewan south to New Mexico and Arizona. Considerable use of this species has been made in range seedings and mined-land reclamation plantings in the northern Great Plains (Thornburg 1982).

Knowledge of the effects of various planting depths on seedling emergence is beneficial in revegetation. Soil moisture conditions generally become more favorable for seed germination with increased plant depth (Rogler 1954, Lawrence 1957, Hyder 1974). Desiccation and inadequate rooting of germinating seedlings result if seeds are not planted deep enough (Vallentine 1980). However if seeds are planted too deep, rate of emergence, total emergence (Vallentine 1980), and vigor (Mutz and Scifres 1975) of seedlings was reduced. On semiarid rangelands, seeds should be planted at a depth sufficient to take advantage of more favorable moisture conditions but not so deep that seedling emergence and vigor are reduced.

Seedling morphology is an important factor influencing seedling emergence and estabishment. Although there are many variations, Hyder et al. (1971) and Hyder (1974) recognized 2 basic morphological types of grass seedlings: (1) the A type, characterized by an elongated subcoleoptile internode and a short coleoptile and (2) the B type, characterized by lack of a subcoleoptile internode elongation and a long coleoptile. Maximum length of the subcoleoptile internode and coleoptile determines the maximum depth from which grass seedlings can emerge. Green needlegrass has the B-type seedling morphology.

The objective of the present study was to determine the influence

\footnotetext{
Authors are former graduate research assistant, Department of Range Science, Colorado State University, Fort Collins, now assistant professor, College of Agriculture, Texas A\&I University, Kingsville, Texas 78363; plant physiologist, USDA-ARS, Crops Research Laboratory, Fort Collins (deceased); and associate professor, Department of Range Science, Colorado State University, Fort Collins 80523.

Research was supported in part by the U.S. Department of Energy under Contract No. DE-AS02-76EV04018.

Manuscript accepted August 13, 1984.
}

of seed source, planting depth, and temperature on morphology and emergence of green needlegrass.

\section{Materials and Methods}

Seeds of 'Lodorm' (a variety of green needlegrass with reduced seed dormancy) and accession SD-93 were obtained from the USDA Soil Conservation Service Plant Materials Center at Bismarck, N. Dak. Seeds were planted in plastic pots $(20 \mathrm{~cm}$ diameter by $20 \mathrm{~cm}$ deep) filled with autoclaved sandy loam soil. Twenty-five seeds were placed in each pot and covered with a thin layer of soil. Soil in each pot was moistened to a water potential of approximately $-0.03 \mathrm{MPa}$. Seeds were then covered with a layer of loose, dry soil to approximate planting depths of $1.5,3.0,4.5,6.0$, and 7.5 $\mathrm{cm}$. Dry surface layers were used to more closely simulate field conditions and to help maintain uniform planting depths. Soil below the dry layer was maintained at approximately field capacity by subirrigating the pots when addition of water was necessary.

Pots were placed in either of 2 growth chambers. One was adjusted for a $20 / 15^{\circ} \mathrm{C}$ and one for a $25 / 20^{\circ} \mathrm{C}(15 \mathrm{~h} \mathrm{light} / 9 \mathrm{~h}$ dark $)$ temperature regime. These temperatures were chosen to simulate spring growing conditions. Photosynthetic photon flux density during the 15 -h photoperiod was $450 \mu \mathrm{E} \mathrm{m}^{-2} \mathrm{sec}^{-1}$.

Seedlings were considered to have emerged when the coleoptile or the leaf was visible at the soil surface. Emerged seedlings were counted and recorded daily for 14 days; the first 5 seedlings to cmerge in cach pot were marked. On the fourteenth day after planting, soil was removed from each pot, placed on a screen, and washed from seedling roots with a fine spray of water. Care was taken to avoid seedling damage.

Marked seedlings were removed from the screen and killed in a $5 \%$ acetic acid solution. Later data from these seedlings from each pot were taken for (1) length of the coleoptile, (2) length of the subcoleoptile internode, (3) length of the seminal root, (4) length from the coleoptilar node to the tip of the longest leaf, and (5) number and length of adventitious roots per seedling. Emergence was calculated on the basis of the percentage of live seed in each source to adjust for differences in viability between seed sources. Rate of emergence was calculated by the equation of Kotowski (1926):

$$
\text { Rate of Seedling Emergence }=\frac{\mathrm{N} \cdot 100}{\Sigma(\mathrm{N} \bullet \mathrm{D})}
$$

where $\mathrm{N}=$ number of seedlings emerged each day and $\mathrm{D}=$ number of days after planting corresponding to each $\mathrm{N}$.

A randomized complete block design with a factorial arrangement of treatments was used in the experiment. Four replications were conducted sequentially over time, and data were analyzed by response surface analysis and analysis of variance (Steel and Torrie 1980). All differences reported were significant at $p<0.05$ unless otherwise stated.

\section{Results}

Subcoleoptile Internode and Coleoptile Elongation

Lengths of the subcoleoptile internode and coleoptile of green 
Table 1. Effect of depth of planting $(\mathrm{cm})$ and temperature regime $\left({ }^{\circ} \mathrm{C}\right)$ on eight seedling characteristics $(\mathrm{cm})$ of two sources of green needlegrass.

\begin{tabular}{|c|c|c|c|c|c|c|c|c|}
\hline \multirow[b]{2}{*}{$\begin{array}{l}\text { Temperature } \\
\text { (light/dark) }\end{array}$} & \multicolumn{8}{|c|}{ Seedling characteristic } \\
\hline & $\begin{array}{l}\text { Source } \\
\text { and depth } \\
\text { of planting }\end{array}$ & $\begin{array}{l}\text { Length of } \\
\text { subcoleoptile } \\
\text { internode }\end{array}$ & $\begin{array}{l}\text { Length } \\
\text { of } \\
\text { coleoptile }\end{array}$ & $\begin{array}{l}\text { Length of } \\
\text { subcoleoptile } \\
\text { internode plus } \\
\text { coleoptile }\end{array}$ & $\begin{array}{l}\text { Length from } \\
\text { coleoptilar node } \\
\text { to tip of } \\
\text { longest leaf }\end{array}$ & $\begin{array}{l}\text { Length of } \\
\text { seminal } \\
\text { root }\end{array}$ & $\begin{array}{l}\text { Number of } \\
\text { adventitious } \\
\text { roots }\end{array}$ & $\begin{array}{l}\text { Length of } \\
\text { adventitious } \\
\text { roots }\end{array}$ \\
\hline $20 / 15$ & $\begin{array}{r}\text { Lodorm } \\
1.5 \\
3.0 \\
4.5 \\
6.0\end{array}$ & $\begin{array}{l}0.7 \\
1.2 \\
1.6 \\
1.4\end{array}$ & $\begin{array}{l}1.4 \\
2.2 \\
3.2 \\
4.0\end{array}$ & $\begin{array}{l}2.1 \\
3.4 \\
4.8 \\
5.4\end{array}$ & $\begin{array}{r}10.4 \\
12.1 \\
13.6 \\
9.3\end{array}$ & $\begin{array}{r}11.4 \\
10.4 \\
9.1 \\
4.3\end{array}$ & $\begin{array}{l}0.6 \\
0.1 \\
0.1 \\
0.0\end{array}$ & $\begin{array}{l}0.7 \\
0.1 \\
0.1 \\
0.0\end{array}$ \\
\hline & $\begin{array}{r}\text { SD-93 } \\
1.5 \\
3.0 \\
4.5 \\
6.0\end{array}$ & $\begin{array}{l}0.5 \\
0.9 \\
1.1 \\
1.1\end{array}$ & $\begin{array}{l}1.5 \\
2.4 \\
3.6 \\
4.6\end{array}$ & $\begin{array}{l}1.9 \\
3.3 \\
4.7 \\
5.7\end{array}$ & $\begin{array}{l}10.9 \\
13.6 \\
15.0 \\
12.6\end{array}$ & $\begin{array}{r}12.5 \\
12.2 \\
10.4 \\
7.2\end{array}$ & $\begin{array}{l}1.0 \\
0.3 \\
0.0 \\
0.0\end{array}$ & $\begin{array}{l}1.3 \\
0.3 \\
0.0 \\
0.0\end{array}$ \\
\hline $25 / 20$ & $\begin{array}{r}\text { Lodorm } \\
1.5 \\
3.0 \\
4.5 \\
6.0\end{array}$ & $\begin{array}{l}0.6 \\
0.9 \\
0.8 \\
0.9\end{array}$ & $\begin{array}{l}1.3 \\
2.3 \\
3.7 \\
3.9\end{array}$ & $\begin{array}{l}1.9 \\
3.2 \\
4.5 \\
4.8\end{array}$ & $\begin{array}{l}13.1 \\
15.3 \\
16.9 \\
12.3\end{array}$ & $\begin{array}{r}14.2 \\
12.4 \\
11.7 \\
7.8\end{array}$ & $\begin{array}{l}0.9 \\
0.9 \\
0.5 \\
0.0\end{array}$ & $\begin{array}{l}5.0 \\
2.4 \\
0.7 \\
0.0\end{array}$ \\
\hline & $\begin{array}{r}\text { SD-93 } \\
1.5 \\
3.0 \\
4.5 \\
6.0\end{array}$ & $\begin{array}{l}0.4 \\
0.5 \\
0.5 \\
0.7\end{array}$ & $\begin{array}{l}1.5 \\
2.7 \\
3.9 \\
4.3\end{array}$ & $\begin{array}{l}2.9 \\
3.1 \\
4.4 \\
5.0\end{array}$ & $\begin{array}{l}13.0 \\
15.9 \\
17.4 \\
14.1\end{array}$ & $\begin{array}{r}14.0 \\
14.1 \\
13.6 \\
8.6\end{array}$ & $\begin{array}{l}1.0 \\
1.0 \\
0.4 \\
0.0\end{array}$ & $\begin{array}{l}5.0 \\
2.7 \\
0.7 \\
0.0\end{array}$ \\
\hline $\begin{array}{l}95 \% \text { Confiden } \\
\text { Interval! }\end{array}$ & & $\bar{x} \pm 0.2$ & $\bar{x} \pm 0.2$ & $\bar{x} \pm 0.2$ & $\bar{x} \pm 1.5$ & $\bar{x} \pm 2.5$ & $\bar{x} \pm 0.2$ & $\bar{x} \pm 0.9$ \\
\hline
\end{tabular}

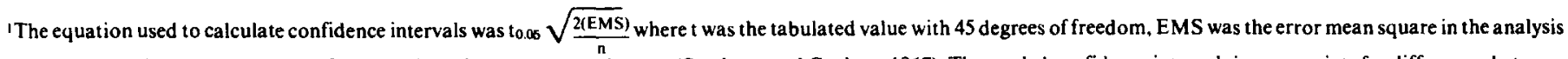

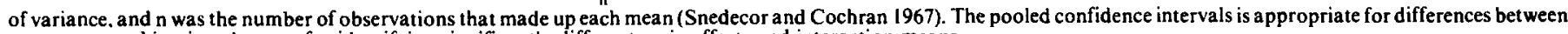
treatment combinations but not for identifying significantly different main effects and interaction means.

needlegrass seedlings increased with planting depth (Table 1). The response of subcoleoptile internode and coleoptile lengths to planting depth consisted of linear and quadratic components (Table 2). Seedlings that emerged from $6.0 \mathrm{~cm}$ (no seedlings emerged from 7.5 $\mathrm{cm}$ ) had longer coleoptiles than seedlings that emerged from shallower planting depths. Subcoleoptile internodes of seedlings that emerged from $4.5 \mathrm{~cm}$ did not differ in length from those of seedlings that emerged from $6.0 \mathrm{~cm}$. Thus, subcoleoptile internodes of

Table 2. Probability of a larger F-value for main effects and interactions in the analysis of variance of data for the effects of planting depth (cm) and temperature regime $\left({ }^{\circ} \mathrm{C}\right)$ on seedling characteristics, percent seedling emergence, and rate of seedling emergence of two sources of green needlegrass.

\begin{tabular}{|c|c|c|c|c|c|c|c|c|c|c|}
\hline $\begin{array}{l}\text { Source } \\
\text { of } \\
\text { variation }\end{array}$ & df & $\begin{array}{l}\text { Length of } \\
\text { subcoleoptile } \\
\text { internode }\end{array}$ & $\begin{array}{l}\text { Length } \\
\text { of } \\
\text { coleoptile }\end{array}$ & $\begin{array}{l}\text { Length of } \\
\text { subcoleoptile } \\
\text { internode } \\
\text { plus } \\
\text { coleoptile }\end{array}$ & $\begin{array}{l}\text { Length from } \\
\text { coleoptilar } \\
\text { node } \\
\text { to tip of } \\
\text { longest leaf }\end{array}$ & $\begin{array}{l}\text { Length of } \\
\text { seminal } \\
\text { root }\end{array}$ & $\begin{array}{l}\text { Number of } \\
\text { adventitious } \\
\text { roots }\end{array}$ & $\begin{array}{l}\text { Length of } \\
\text { adventitious } \\
\text { roots }\end{array}$ & $\begin{array}{c}\text { Percent } \\
\text { emer- } \\
\text { gence }\end{array}$ & $\begin{array}{c}\text { Rate of } \\
\text { emergence }\end{array}$ \\
\hline Block & 3 & 0.11 & 0.45 & 0.60 & 0.28 & 0.39 & 0.36 & 0.48 & 0.04 & 0.42 \\
\hline Temperature (T) & 1 & $<0.01$ & 0.05 & $<0.01$ & $<0.01$ & $<0.01$ & $<0.01$ & $<0.01$ & 0.15 & 0.01 \\
\hline Seed Source (S) & 1 & $<0.01$ & $<0.01$ & 0.53 & $<0.01$ & $<0.01$ & 0.03 & 0.33 & 0.26 & $<0.01$ \\
\hline Depth (D) & 3 & & & & & & & & & \\
\hline Linear (L) & 1 & $<0.01$ & $<0.01$ & $<0.01$ & 0.08 & $<0.01$ & $<0.01$ & $<0.01$ & $<0.01$ & $<0.01$ \\
\hline Quadratic $(Q)$ & 1 & $<0.01$ & $<0.01$ & $<0.01$ & $<0.01$ & $<0.01$ & 0.30 & $<0.01$ & $<0.01$ & 0.01 \\
\hline Cubic (C) & 2 & 0.84 & $<0.01$ & $<0.01$ & $<0.01$ & 0.56 & 0.46 & 0.83 & 0.44 & 0.13 \\
\hline $\mathrm{T} \times \mathrm{S}$ & 1 & 0.48 & 0.62 & 0.81 & 0.07 & 0.13 & 0.18 & 0.57 & 0.26 & 0.05 \\
\hline$T \times D$ & 3 & & & & & & & & & \\
\hline$T \times L$ & 1 & $<0.01$ & 0.34 & $<0.01$ & 0.87 & 0.45 & 0.01 & $<0.01$ & $<0.01$ & $<0.01$ \\
\hline $\mathbf{T} \times \vec{Q}$ & 1 & $<0.01$ & $<0.01$ & 0.04 & 0.35 & 0.43 & $<0.01$ & 0.12 & 0.02 & 0.07 \\
\hline $\mathrm{T} \times \mathrm{C}$ & $i$ & 0.08 & 0.08 & 0.98 & 0.82 & 0.13 & $<0.01$ & 0.36 & 0.61 & 0.13 \\
\hline $\mathrm{S} \times \mathrm{D}$ & 3 & & & & & & & & & \\
\hline $\mathrm{S} \times \mathrm{L}$ & 1 & 0.57 & $<0.01$ & $<0.01$ & $<0.01$ & 0.20 & 0.01 & 0.27 & 0.38 & 0.67 \\
\hline $\mathbf{S} \times \vec{Q}$ & l & 0.04 & 0.98 & 0.05 & 0.50 & 0.20 & 0.58 & 0.76 & 0.28 & 0.24 \\
\hline $\mathrm{S} \times \mathrm{C}$ & 1 & 0.84 & 0.36 & 0.30 & 0.27 & 0.70 & 0.17 & 0.67 & 0.66 & 0.25 \\
\hline $\mathbf{T} \times \mathbf{S} \times \mathbf{D}$ & 3 & & & & & & & & & \\
\hline $\mathrm{T} \times \mathbf{S} \times \mathbf{L}$ & 1 & 0.27 & 0.08 & 0.53 & 0.58 & 0.58 & 0.19 & 0.48 & 0.59 & 0.49 \\
\hline $\mathrm{T} \times \mathrm{S} \times \mathbf{Q}$ & $i$ & 0.98 & 0.82 & 0.81 & 0.93 & 0.69 & 0.81 & 0.57 & 0.87 & 0.99 \\
\hline $\mathrm{T} \times \mathrm{S} \times \mathrm{C}$ & $i$ & 0.33 & 0.25 & 0.88 & 0.84 & 0.60 & 0.70 & 0.68 & 0.58 & 0.41 \\
\hline Error 45 & & & & & & & & & & \\
\hline
\end{tabular}


green needlegrass seedlings reached maximum length when emerging from planting depths shallower than the depth from which coleoptiles reached maximum length. Subcoleoptile internodes of seedlings that emerged from $6.0 \mathrm{~cm}$ averaged $1.0 \mathrm{~cm}$ in length, while coleoptiles averaged $4.2 \mathrm{~cm}$.

Differences in subcoleoptile internode and coleoptile lengths of green needlegrass seedlings existed between sources and between temperature treatments (Tables 1 and 2). 'Lodorm' seedlings had longer subcoleoptile internodes and shorter coleoptiles than did SD-93 seedlings when averaged over planting depths and temperature treatments. Reach of the coleoptile above planting depth (length of the subcoleoptile internode plus coleoptile) did not differ between sources. Average subcoleoptile internodes of seedlings grown under the $20 / 15^{\circ} \mathrm{C}$ temperature regime were longer than those of seedlings grown under the $25 / 20^{\circ} \mathrm{C}$ regime. Although coleoptiles of seedlings grown under the warmer regime were longer, total reach of the coleoptiles above planting depth was greater for seedlings grown under the cooler regime because of the longer subcoleoptile internode lengths at cooler temperatures.

The reason seedlings had shorter subcoleoptile internodes under the warmer regime is unknown. Possibly soil humidity in the zone of subcoleoptile internode elongation may have differed between the 2 temperature regimes.

\section{Shoot and Root Growth}

Shoot length (length from the coleoptilar node to the tip of the longest leaf) exhibited a quadratic and cubic response to planting depth (Tables 1 and 2). Shoot lengths were least for seedlings that emerged from the 1.5 and $6.0-\mathrm{cm}$ planting depths, and greatest for seedlings that emerged from $4.5 \mathrm{~cm}$. Emerging seedlings depend upon stored energy in the caryopsis to support root and shoot elongation. As planting depth is increased, more energy is required for shoot elongation and less energy is available for initial vegetative growth (Mutz and Scifres 1975). Seedlings in this study that emerged from $6.0 \mathrm{~cm}$ had shorter shoots than seedlings tht emerged from $4.5 \mathrm{~cm}$.

In addition, seminal primary root length, number of adventitious roots, and length of adventitious roots per seedling decreased with increased plant depth (Tables 1 and 2). Apparently, as planting depth was increased, seedlings utilized relatively more of the stored material in the caryopsis for coleoptile elongation and relatively less substrate was available for seminal primary root growth and initial leaf growth. Seedlings that emerged from $6.0 \mathrm{~cm}$ had longer coleoptiles and shorter seminal primary roots than seedlings that emerged from shallower planting depths as a result.

Differences in shoot and root development existed between accessions and between temperature regimes (Table 2). The SD-93 seedlings emerged sooner (Fig. 1) and had longer shoots, longer seminal primary roots, and more adventitious roots than 'Lodorm' seedlings (Table 1 ). All seedlings grown under the $25 / 20^{\circ} \mathrm{C}$ regime emerged sooner and had longer shoots, longer seminal primary roots, and longer and more adventitious roots than seedlings grown under the $20 / 15^{\circ} \mathrm{C}$ regime.

\section{Seedling Emergence}

Emergence and rate of emergence of green needlegrass seedlings decreased linearly and quadratically with planting depth (Figs. 1 and 2, Table 2). Coleoptiles of seedlings that emerged from the 1.5 $\mathrm{cm}$ soil depth extended $0.4 \mathrm{~mm}$ above the surface (Fig. 3). Reach of the coleoptile above planting depth of seedlings that emerged from $6.0 \mathrm{~cm}$ averaged $5.2 \mathrm{~cm}$ because coleoptiles of a number of seedlings failed to reach the soil surface. Emergence of many seedlings from $6.0 \mathrm{~cm}$ depended on the ability of the first foliage leaf to force its way through the dry, loose surface soil because their coleoptiles did not reach the soil surface. The leaf was poorly adapted for emergence because of the long, soft meristematic region at the base inside the coleoptile (Hyder et al. 1971, Hyder 1974). Since the leaf was poorly adapated for emergence, percentage emergence from $6.0 \mathrm{~cm}$ was greatly reduced.

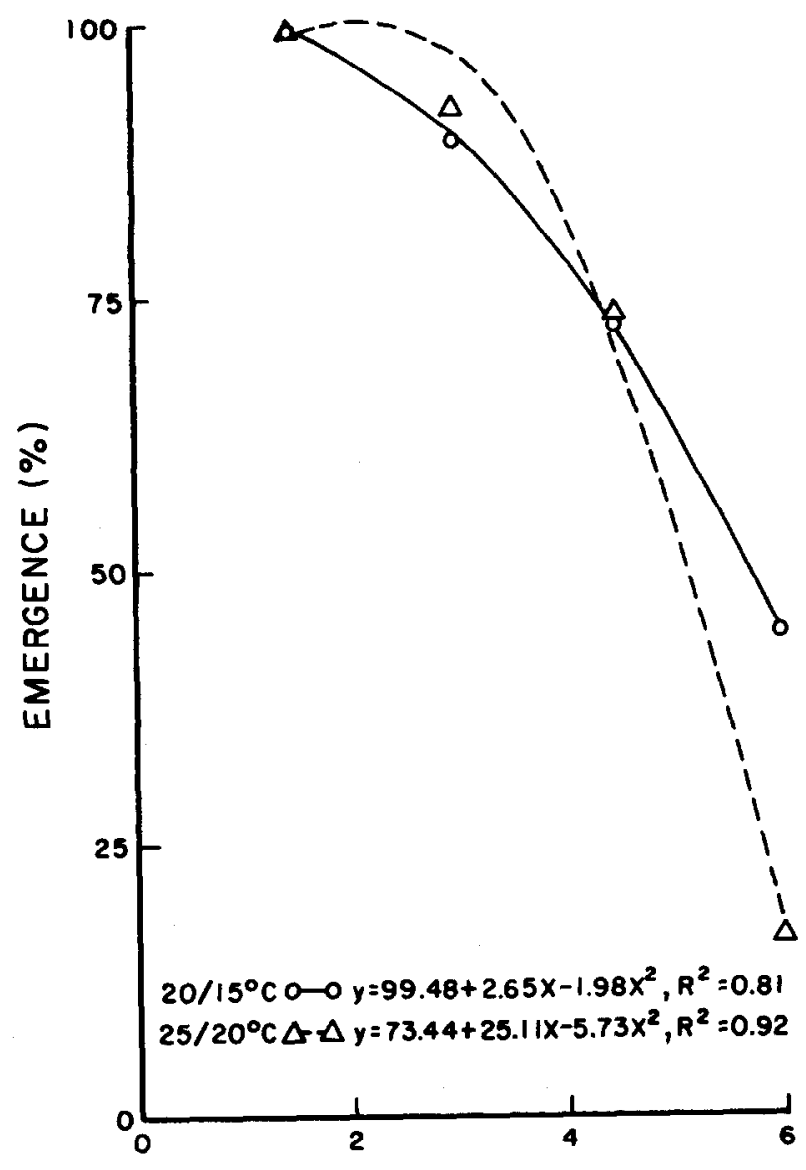

PLANTING DEPTH $(\mathrm{cm})$

Fig. 1. Planting depth effects on percent emergence of green needlegra. seedlings under 2 temperatures regimes. The 95\% confidence interv associated with the means was $\bar{x} \pm 2.7$. The equation used to calcula the confidence interval was to.05 $\sqrt{\frac{2(E M S)}{n}}$ where t was the tabulatec value, EMS was the error mean square in the analysis of variance, and was the number of observations that made up each mean (Snedecor ar: Cochran 1967). The pooled confidence intervals is appropriate for diffe ences between treatment combinations but not for identifying signij cantly different main effects and interaction means.

Emergence differed between temperature regimes only for see lings that emerged from the 6.0-cm planting depth (Fig. 1). Few seedlings emerged from the $6.0-\mathrm{cm}$ planting depth under th $25 / 20^{\circ} \mathrm{C}$ temperature regime than under the $20 / 15^{\circ} \mathrm{C}$ regin because of the reduction in subcoleoptile internode length at $\mathrm{tl}$ warmer temperature (Table 1). Since subcoleoptile internod, were shorter at $25 / 20^{\circ} \mathrm{C}$, fewer seedlings were able to extend the coleoptiles to the soil surface from the $6.0-\mathrm{cm}$ planting depth. $N$ difference in percentage emergence existed between green needl grass sources since reach of the coleoptile above planting depth $\mathrm{d}$ not differ between sources.

\section{Discussion}

Blue grama (Bouteloua gracilis (H.B.K.) Lag.) seedlings have short coleoptile and an elongated subcoleoptile internode. T1 type A seedling morphology of blue grama places the coleoptili node, from which adventitious roots develop, near the soil surfa where environmental conditions on semiarid rangelands are no mally unfavorable for development of adventitious roots (Hyder al. 1971; Hyder 1974; Briske and Wilson 1978, 1980). The lor coleoptile of green needlegrass should be beneficial for seedli establishment since the coleoptilar node remains near plantil 


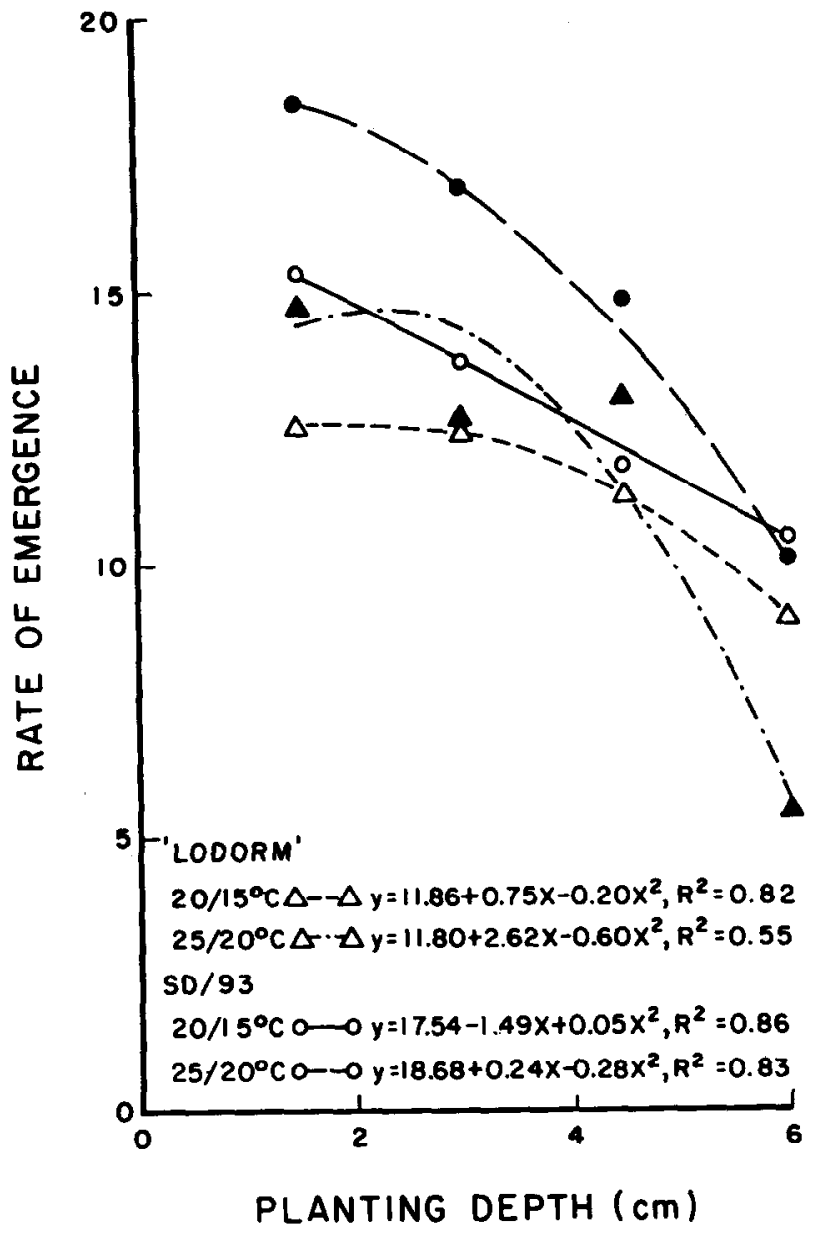

Fig. 2. Planting depth effects on rate of seedling emergence of 2 sources of green needlegrass under 2 temperature regimes. The $95 \%$ confidence interval associated with the means was $\bar{x} \pm 3.6$. The equation used to calculate the confidence interval was to.05 $\sqrt{\frac{2(E M S)}{n}}$ where $t$ was the tabulated $t$ value, EMS was the error mean square in the analysis of variance, and $n$ was the number of observations that made up each mean (Snedecor and Cochran 1967). The pooled confidence interval is appropriate for differences between treatment combinations but not for identifying significantly different main effects and interaction means.

depth where environmental conditions are usually more favorable for adventitious root development. Hyder et al. (1971) and Hyder (1974) reported that seedlings of crested wheatgrass (Agropyron desertorum (Fisch.) Schult.) are more likely to survive on semiarid rangelands than blue grama seedlings because the type B seedling morphology of crested wheatgrass places the coleoptilar node near the planting depth. Although both crested wheatgrass and green needlegrass have long coleoptiles, seedling morphology of these 2 species differs in that at greater planting depths the intracoleoptile internode (Hyder 1974) of crested wheatgrass seedlings elongates, but there is no elongation of the subcoleoptile internode as in green needlegrass.

The proper depth at which to plant green needlegrass will depend on factors such as soil moisture and soil texture. Moist or finer textured soil would have offered more resistance to emerging coleoptiles and possibly would have reduced emergence more than the soil used in this study. In greenhouse studies 'Lodorm'seedlings exhibited only $9 \%$ emergence from a planting depth of $2.5 \mathrm{~cm}$ in clay textured soil (E.F. Redente, unpublished data). Extrapolation of the results of the present study to aid in selection of proper planting depths for green needlegrass seeds in the field should be approached with caution since seedling emergence was examined

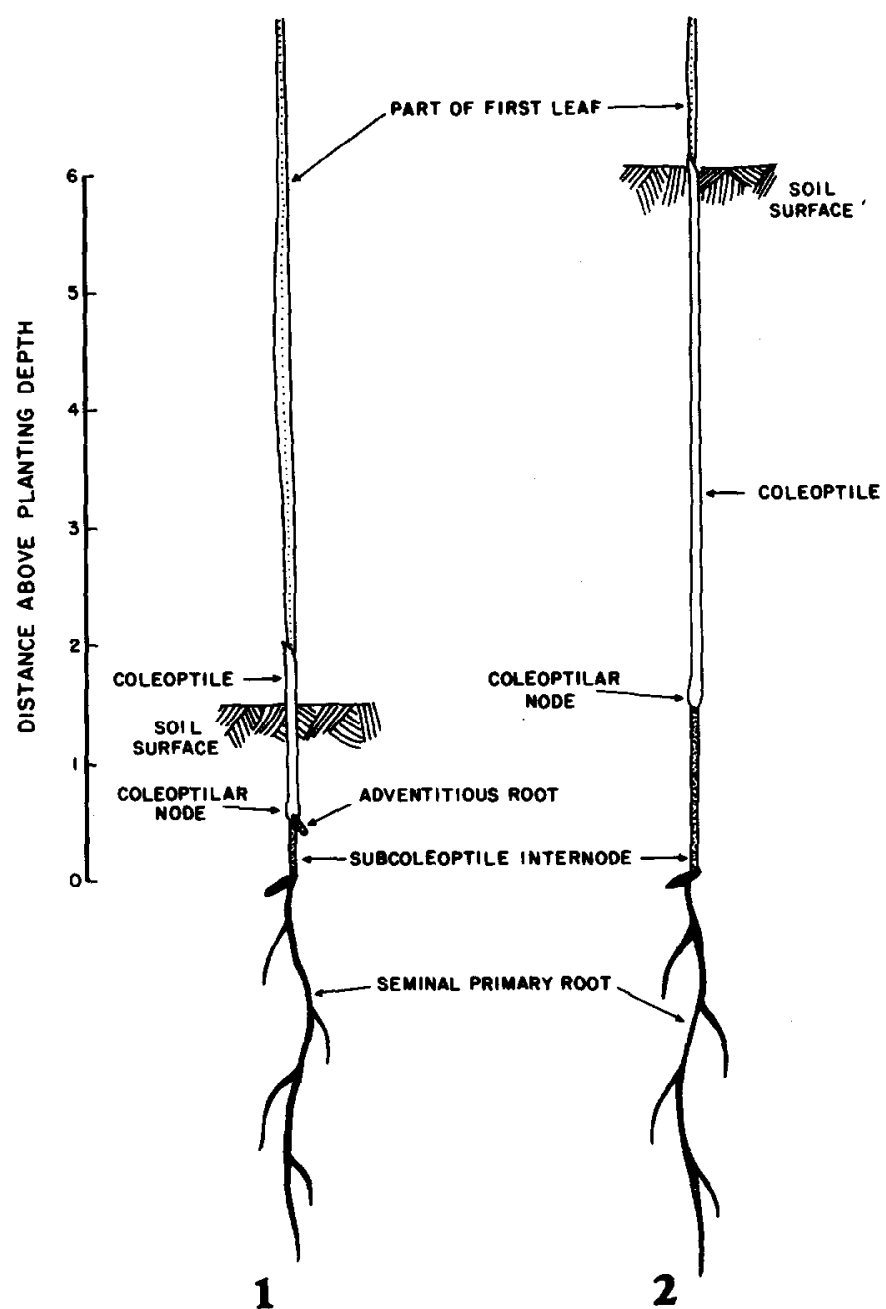

Fig. 3. Examples of green needlegrass seedlings that emerged from planting depths of $1.5 \mathrm{~cm}$ (1) and 6.0 (2).

from one soil texture and since pots were watered by subirrigation, which is not a normal condition on rangelands. However, results did indicate that seeds of green needlegrass generally should not be planted at depths greater than $3.0 \mathrm{~cm}$ because of (1) lower percent emergence, (2) lower rate of emergence, and (3) poor root development when seedlings emerged from greater depths.

\section{Literature Cited}

Briske, D.D., and A.M. Wilson. 1978. Moisture and temperature requirements for adventitious root development in blue grama seedlings. J. Range Manage. 31:174-178.

Briske, D.D., and A.M. Wilson. 1980. Drought effects on adventitious root development in blue grama seedlings. J. Range Manage. 33:323-326.

Hyder, D.N. 1974. Morphogenesis and management of perennial grasses in the United States. P. 89-98. In: Plant morphogenesis as the basis for scientific management of range resources. Proc., Workshop of the U.S./Australian Rangelands Panel (29 Mar-5 Apr 1971, Berkeley, Calif.). USDA Misc. Pub. 1271.

Hyder, D.N., A.C. Everson, and R.E. Bement. 1971. Seedling morphology and seeding failures with blue grama. J. Range Manage. 24:287-292.

Kotowski, F. 1926. Temperature relations to germination of vegetable seeds. Proc. Amer. Soc. Hort. Sci. 23:176-184.

Lawrence, T. 1957. Emergence of intermediate wheatgrass lines from five depths of seeding. Can. J. Plant Sci. 37:215-219.

Mutx, J.L., and C.J. Scifres. 1975. Soil texture and planting depth influence buffalograss emergence. J. Range Manage. 28:222-224.

Rogler, G.A. 1954. Seed size and seedling vigor in crested wheatgrass. Agron. J. 46:216-220. 
Snedecor, G.W., and W.G. Cochran. 1967. Statistical methods, 6th ed. lowa State Univ. Press, Ames, lowa.

Steel, R.G.D., and J.H. Torrie. 1980. Principles and procedures of statistics -A biometrical approach. McGraw-Hill Book Company, Inc., New York.
Thornburg, A.A. 1982. Plant materials for use on surface-mined lands in arid and semiarid regions. USDA Soil Conserv. SCS-TP-157.

Vallentine, J.F. 1980. Range development and improvements, 2nd ed. Brigham Young Univ. Press, Provo, Utah. 